\title{
Investigation of the Heterovalent Substitution Cadmium for Lanthanum in Molybdate $\mathrm{La}_{2} \mathrm{MoO}_{6}$
}

\author{
K. A. Chebyshev $\mathbb{D}^{1}{ }^{1}$ A. V. Ignatov $\mathbb{D}^{1}{ }^{1}$ L. V. Pasechnik ${ }^{1},{ }^{1}$ N. I. Selikova ${ }^{1},{ }^{1}$ \\ and E. I. Get'man (iD) \\ ${ }^{1}$ Department of Inorganic Chemistry, Donetsk National University, Donetsk 83001, Ukraine \\ ${ }^{2}$ Department of Analytical Chemistry, Donetsk National University, Vinnytsia 21021, Ukraine \\ Correspondence should be addressed to K. A. Chebyshev; chebyshev.konst@mail.ru
}

Received 7 February 2021; Revised 12 May 2021; Accepted 22 May 2021; Published 28 May 2021

Academic Editor: Liviu Mitu

Copyright ( $\odot 2021$ K. A. Chebyshev et al. This is an open access article distributed under the Creative Commons Attribution License, which permits unrestricted use, distribution, and reproduction in any medium, provided the original work is properly cited.

\begin{abstract}
This paper presents the investigation of the heterovalent substitution of cadmium for lanthanum in the $\mathrm{La}_{2-\mathrm{x}} \mathrm{Cd}_{\mathrm{x}} \mathrm{MoO}_{6-\mathrm{x} / 2}$ system. The samples were synthesized by the solid state reaction method at $1000^{\circ} \mathrm{C}$. The samples were characterized by X-ray powder diffraction with Rietveld refinements, scanning electron microscopy with energy-dispersive X-ray spectroscopy, and Fourier transform infrared spectroscopy methods. The study results revealed that cadmium incorporation in the lanthanum molybdate leads to the transformation of the tetragonal structure of $\mathrm{La}_{2} \mathrm{MoO}_{6}$ to a cubic fluorite-like one. The content of the cubic phase reaches $94 \%$ in the $\mathrm{La}_{1.4} \mathrm{Cd}_{0.6} \mathrm{MoO}_{5.7}$ sample. The unit cell parameter of fluorite-like-phase decreases with cadmium content rising. The preferred location of cadmium ions in the cubic structure was established by the Rietveld refinement method. The heterovalent substitution cadmium for lanthanide in tetragonal $\mathrm{La}_{2} \mathrm{MoO}_{6}$ molybdate leads to the cubic fluorite phase stabilization in a similar way as it occurs in the process of reduction.
\end{abstract}

\section{Introduction}

Molybdates of rare-earth elements (REE) have various compositions depending on the ratio of cations, for example, $\mathrm{Ln}_{2}\left(\mathrm{MoO}_{4}\right)_{3}, \quad \mathrm{Ln}_{2} \mathrm{MoO}_{6}, \quad \mathrm{Ln}_{5} \mathrm{Mo}_{3} \mathrm{O}_{16+\delta}, \quad$ and $\mathrm{Ln}_{4} \mathrm{MoO}_{9}$. Among them, $\mathrm{Ln}_{2} \mathrm{MoO}_{6}$ compounds attract attention for potential using luminophores, catalysts, ionic conductors, and so forth [1-3]. Structures of REE molybdates $\mathrm{Ln}_{2} \mathrm{MoO}_{6}$ may change resulting from a value of lanthanide ionic radii and synthesis conditions. The monoclinic structure (space group $\mathrm{C} 2 / \mathrm{c}, z=8)$ is typical for REE molybdates $\mathrm{Ln}_{2} \mathrm{MoO}_{6}$, where $\mathrm{Ln}=\mathrm{La}$ to $\mathrm{Lu}$ as well as $\mathrm{Y}[4,5]$. Besides this, REE molybdates with lanthanides from La to Sm can crystallize in the tetragonal structure (space group I41/acd, $z=4$ ) [6]. The low-temperature modification of neodymium molybdate (space group I2/c, $z=8$ ) was described. It was formed at $800^{\circ} \mathrm{C}$ by a solution-melt method from a mixture of 25 mole $\% \mathrm{Nd}_{2} \mathrm{O}_{3}+55$ moles\% $\mathrm{MoO}_{3}+10$ moles\% $\mathrm{PbO}$ [7], where lead oxide was used to decrease the melting point of the mixture.
Compounds $\mathrm{Ln}_{5} \mathrm{Mo}_{3} \mathrm{O}_{16+\delta}$ with cubic fluorite-like structure (space group $\mathrm{Pn}-3 \mathrm{n}$ ) are known for $\mathrm{Nd}$ and $\operatorname{Pr}[8]$. Molybdenum content in such compounds is slightly higher than that in $\mathrm{Ln}_{2} \mathrm{MoO}_{6}$ molybdates (calculated value for $\mathrm{MoO}_{3}$ is 54.5 mole\%). The value of $\delta$ may range from 0 up to 0.5 because some of molybdenum ions may be reduced to a lower oxidation state during synthesis [6]. Isostructural molybdates $\mathrm{Ln}_{5} \mathrm{Mo}_{3} \mathrm{O}_{16}(\delta=0)$ for REE from La to Tb with cubic fluorite-like structure were obtained in reducing conditions $[9,10]$.

Lanthanum molybdate $\mathrm{La}_{5} \mathrm{Mo}_{3} \mathrm{O}_{16+\delta}(\delta=0.5)$ is unstable in oxidizing conditions and decomposes into the mixture of compounds $\mathrm{La}_{2} \mathrm{MoO}_{6}$ and $\mathrm{La}_{2} \mathrm{Mo}_{2} \mathrm{O}_{9}$ [9]. Molybdates $\mathrm{Ln}_{5} \mathrm{Mo}_{3} \mathrm{O}_{16+\delta}$ with the monoclinic structure were synthesized for REEs following after $\mathrm{Nd}$ in oxidizing conditions. The latter molybdates are obviously a part of the homogeneity region of $\mathrm{Ln}_{2} \mathrm{MoO}_{6}$ compounds (space group $\mathrm{C} 2 / \mathrm{c}$, $z=8)$.

It is noteworthy that all crystal structures of REE molybdates and close compounds by composition are 
derivatives from the fluorite structure and differ by a manner of its distortion.

Compounds with the general formula $\mathrm{MLn}_{4} \mathrm{Mo}_{3} \mathrm{O}_{16}$ with a cubic structure for REE from La to Lu are stabilized by the substitution of a double-charged metal ion, $\mathrm{M}^{+2}$ for the lanthanide ion [11]. The temperature of synthesis increases as the REE atomic number increases and also depends on the nature of the double-charged metal ion. The incorporation of cadmium or lead ions leads to a decrease in temperature of the cubic structure formation while alkaline earth ions increase it.

The cubic molybdates $\mathrm{Ln}_{2} \mathrm{MoO}_{5}$ with fluorite structure for $\mathrm{Ln}=\mathrm{Gd}, \mathrm{Tb}, \mathrm{Dy}, \mathrm{Ho}$, and $\mathrm{Y}$ were prepared by reduction of $\mathrm{Ln}_{2} \mathrm{MoO}_{6}$ with hydrogen [12]. In recent years due to increased interest in ionic oxygen conductors with high conductivity at medium temperatures $\left(200-900^{\circ} \mathrm{C}\right)$, compounds $\mathrm{Ln}_{2} \mathrm{MoO}_{6-\delta}$ with fluorite structure, where $\mathrm{Ln}=\mathrm{Tb}-\mathrm{Yb}$, were studied in the systems $\mathrm{Ln}_{2} \mathrm{O}_{3}-\mathrm{MoO}_{3}[13]$. The fluorite-like structure of $\mathrm{La}_{2} \mathrm{MoO}_{6-\delta}$ was also obtained by hydrogen reduction of tetragonal lanthanum molybdate $\mathrm{La}_{2} \mathrm{MoO}_{6}$ [14]. It has high conductivity, which makes using it as anode materials in solid oxide fuel cells possible.

The compounds $\operatorname{Ln}_{2} \mathrm{MoO}_{6}$ with the structure derived from fluorite can also be modified by a heterovalent substitution of the double-charged metal ion for lanthanide ion. It presumably enables obtaining a similar material with the vacancies in the oxygen sublattice but without the electronic component of conductivity.

The solid solutions $(\mathrm{PbO})_{\mathrm{x}}\left(\mathrm{La}_{2} \mathrm{MoO}_{6}\right)_{(1-x) / 2}$ with constant La:Mo ratio synthesized by the solid state method were described in work [15]. The solid solutions were isostructural to lanthanum molybdate $\mathrm{La}_{2} \mathrm{MoO}_{6}$ with tetragonal structure and the heterovalent substitution did not cause transformation of the structure.

Earlier, we reported the heterovalent substitution of cadmium for REE in monoclinic gadolinium and holmium molybdates $\mathrm{Ln}_{2} \mathrm{MoO}_{6}$ resulted in the formation of cubic fluorite-like phases [16]. For these compositions, the $\mathrm{Ln}$ : Mo ratio varies but the $(\mathrm{Ln}+\mathrm{Cd})$ : Mo ratio remains constant.

At the same time, there is no information about the possibility of the cubic fluorite-like structure stabilization upon substitution cadmium for REE in $\mathrm{Ln}_{2} \mathrm{MoO}_{6}$ molybdates with the tetragonal structure. The aim of this study is the investigation of $\mathrm{La}_{2} \mathrm{MoO}_{6}$ molybdate transformation to the cubic structure by substitution of cadmium for lanthanum.

\section{Materials and Methods}

The samples with a composition that corresponds to the following ratio of reagents $(1-x / 2) \mathrm{La}_{2} \mathrm{O}_{3} \cdot \mathrm{xCdO} \cdot \mathrm{MoO}_{3}$ $(0 \leq x \leq 1)$ were synthesized by the solid state method from the stoichiometric mixtures of oxides (analytical grade, Synbias). Apparently, the replacement of cadmium ion for triple charged ion of REE in the structure of $\mathrm{La}_{2} \mathrm{MoO}_{6}(x=0)$ results in the removal of oxygen for charges compensation in the crystal structure and formation of solid solutions with general formula $\mathrm{La}_{2-x} \mathrm{Cd}_{x} \mathrm{MoO}_{6-x / 2}$. The lack of oxygen in the structure leads to the transformation of the tetragonal structure to the cubic one as it takes place in the compounds $\mathrm{Ln}_{2} \mathrm{MoO}_{6-\delta}$.

The substitution of cadmium for lanthanum in the crystal structure occurs under the suggested scheme:

$\mathrm{La}^{+3}+1 / 2 \mathrm{O}^{-2}=\mathrm{Cd}^{+2}+1 / 2 \mathrm{~V}_{\mathrm{O}}$.

The set of all synthesized samples is hereinafter mentioned as "system $\mathrm{La}_{2-x} \mathrm{Cd}_{x} \mathrm{MoO}_{6-x / 2}$ ".

The initial oxides were calcined $\left(\mathrm{La}_{2} \mathrm{O}_{3}\right.$ at $1000^{\circ} \mathrm{C}$ for 1 hour; $\mathrm{CdO}$ and $\mathrm{MoO}_{3}$ at $500^{\circ} \mathrm{C}$ for 4 hours) prior to synthesis. The homogenized mixtures of oxides were annealed at $500^{\circ} \mathrm{C}$ for 5 hours to fully bind $\mathrm{MoO}_{3}$. Then, samples were annealed at $800^{\circ} \mathrm{C}, 950^{\circ} \mathrm{C}$, and $1000^{\circ} \mathrm{C}$ for 10,20 , and 10 hours, respectively. The subsequent increase in temperature or increase in time of annealing results in a considerable samples' composition change due to sublimation of cadmium oxide. After annealing, each sample was homogenized and studied by the XRD method. The annealing was performed at each temperature until samples' consistent phase composition was attained.

$\mathrm{X}$-ray powder diffraction patterns of the samples were recorded at room temperature using Rigaku Ultima IV and modernized electronically controlled DRON-3 diffractometers, using $\mathrm{Ni}$-filtered $\mathrm{CuK}_{\alpha}$ radiation at a scanning rate of $2^{\circ}(2 \theta) / \mathrm{min}$ in the range $25 \leq 2 \theta \leq 60^{\circ}$. To obtain data for crystal structure refinement by the Rietveld procedure, the samples were scanned in steps of $0.05^{\circ}(2 \theta)$ in the range $15^{\circ} \leq 2 \theta \leq 140^{\circ}$ with a counting time of $3 \mathrm{~s} / \mathrm{step}$. The data were analyzed with the program FullProf.2k and the WinPLOTR graphical interface. As starting data in the refinement, atomic coordinates in the structure were taken [15].

A JSM-6490LV (JEOL, Japan) scanning electron microscope and INCA Penta FETx3 (Oxford Instruments, England) energy-dispersive spectrometer were used for the samples' investigation. The data for elemental analysis were collected in 38 fragments of the sample surface.

IR spectra of the samples dispersed in $\mathrm{KBr}$ tablets were recorded in the wavenumber range from 400 to $4000 \mathrm{~cm}^{-1}$ with a TENSOR 27 (Bruker Optics) Fourier transform infrared spectrophotometer. The materials and methods section should contain sufficient detail so that all procedures can be repeated. It may be divided into headed subsections if several methods are described.

\section{Results and Discussion}

The X-ray patterns of the samples $\mathrm{La}_{2-x} \mathrm{Cd}_{x} \mathrm{MoO}_{6-x / 2}$ are represented in Figure 1. The unmodified lanthanum molybdate is the single-phase sample with a tetragonal structure (space group, I41/acd). The substitution of cadmium for lanthanum results in the formation of the cubic fluorite-like structure in the full range of compositions. The reflections of $\mathrm{La}_{2} \mathrm{MoO}_{6}$ with the tetragonal structure are observed in the $\mathrm{X}$-ray patterns in the range $x=0-0.5$ and their intensities decrease as $x$ value increases. The cadmium oxide phase forms in the range $x=0.2-1.0$. The X-ray patterns of the samples with $x \geq 0.8$ also contain the reflections of cadmium molybdate.

The content of lanthanum molybdate with tetragonal structure linearly decreases with the increase of cadmium in 


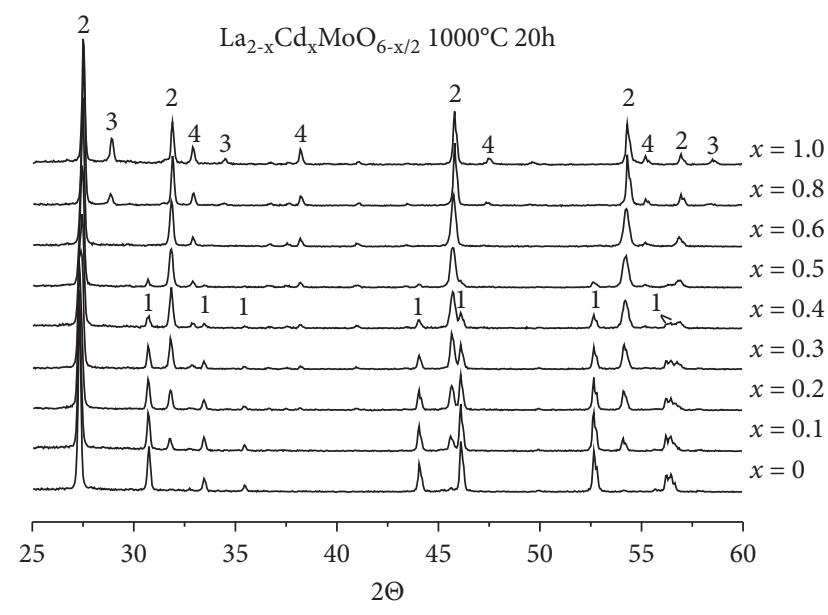

FIgURE 1: X-ray diffraction patterns of $\mathrm{La}_{2-x} \mathrm{Cd}_{x} \mathrm{MoO}_{6-x / 2}$ (1: tetragonal $\mathrm{La}_{2} \mathrm{MoO}_{6} ; 2$ : cubic fluorite-related phase; 3: cadmium molybdate; and 4: cadmium oxide).

a sample (see Figure 2). At the same time, the content of the cubic fluorite-like phase reaches $\approx 94 \%$ in the sample with $x=0.6$. A decrease in the cubic phase content is caused by the formation of cadmium molybdate in the samples with higher $x$ values. The phase of cadmium oxide appears in the X-ray pattern of the sample with $x=0.2$ and its content reaches $8 \%$ at $x=1.0$.

The substitution of cadmium for lanthanum has not caused a substantial change of unit cell parameters of $\mathrm{La}_{2} \mathrm{MoO}_{6}$ with the tetragonal structure (see Table 1). Evidently, the solid solutions with the tetragonal phase $\mathrm{La}_{2} \mathrm{MoO}_{6}$ have not formed in the system $\mathrm{La}_{2-x} \mathrm{Cd}_{x} \mathrm{MoO}_{6-x / 2}$ or the region of their existence is very narrow.

All synthesized samples contained at least two phases. It is known that a region of single-phase solid solutions expands as temperature increases. So, an increase in temperature will presumably result in the formation of the single-phase samples in this system. To prevent cadmium oxide sublimation which occurs at high temperatures, the atmosphere with greater pressure of volatile component has to be created as it was made in the study [17] for $\mathrm{CdY}_{4} \mathrm{Mo}_{3} \mathrm{O}_{16}$ single crystal growing.

The samples $\mathrm{La}_{1.4} \mathrm{Cd}_{0.6} \mathrm{MoO}_{5.7}$ with the highest quantity of the cubic structure were investigated using a scanning electron microscope. In the conditions of synthesis, the powders with the particles' size of about $1 \mu \mathrm{m}$ were produced (see Figure 3). According to the result of local energy-dispersive X-ray spectroscopic microanalysis, the general composition of the sample corresponds to the formula $\mathrm{La}_{1.47} \mathrm{Cd}_{0.58} \mathrm{Mo}_{1.00} \mathrm{O}_{5.86}$. So, there is a good correlation between the theoretical and the experimentally determined composition of the sample. It reveals that the sublimation of volatile components did not occur during the synthesis.

The dependence of the cubic fluorite-like structure unit cell parameter on cadmium content has three regions (see Figure 4). The parameter equals 11.248(2) $\AA$ and does not change when the quantity of cadmium is at minimum $(\Psi=0.1-0.2)$ and then it decreases to $11.200(2)$ with increasing cadmium content in the range of $x$ from 0.2 to 0.8 .

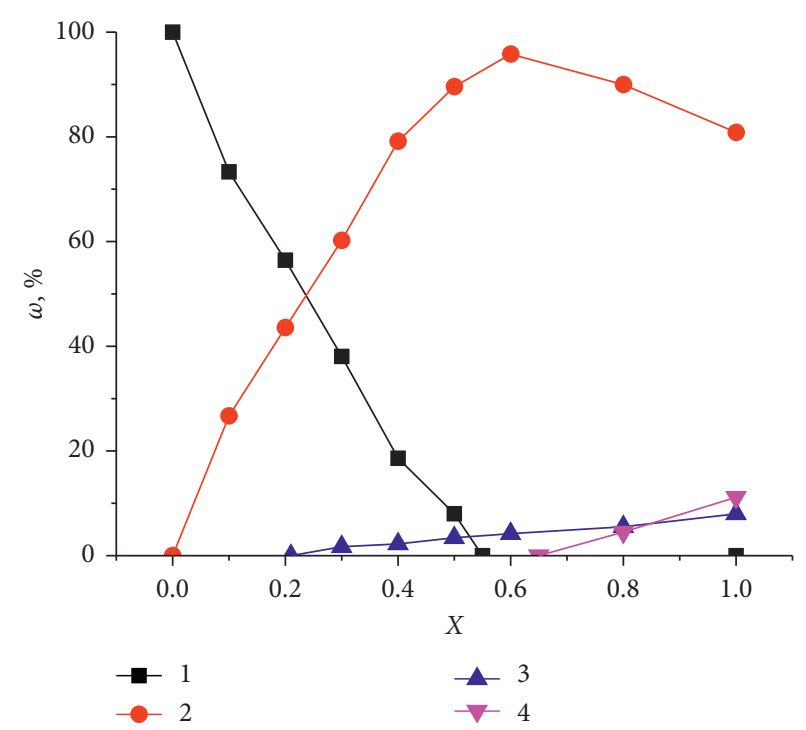

FIgURE 2: The phases content of $\mathrm{La}_{2-x} \mathrm{Cd}_{x} \mathrm{MoO}_{6-x / 2}$ (1: tetragonal $\mathrm{La}_{2} \mathrm{MoO}_{6} ; 2$ : cubic fluorite-related phase; 3 : cadmium molybdate; and 4: cadmium oxide).

TABLE 1: The unit cell parameters of the tetragonal phase $\mathrm{La}_{2} \mathrm{MoO}_{6}$.

\begin{tabular}{lcc}
\hline Composition of $\mathrm{La}_{2-x} \mathrm{Cd}_{x} \mathrm{MoO}_{6-x / 2}$ & $\mathrm{a}(\AA)$ & $\mathrm{c}(\AA)$ \\
\hline $\mathrm{La}_{2} \mathrm{MoO}_{6}[6]$ & $5.79701(3)$ & $32.0353(3)$ \\
$x=0$ & $5.8009(5)$ & $32.049(3)$ \\
$x=0.2$ & $5.8010(5)$ & $32.053(3)$ \\
$x=0.4$ & $5.7992(6)$ & $32.040(4)$ \\
\hline
\end{tabular}

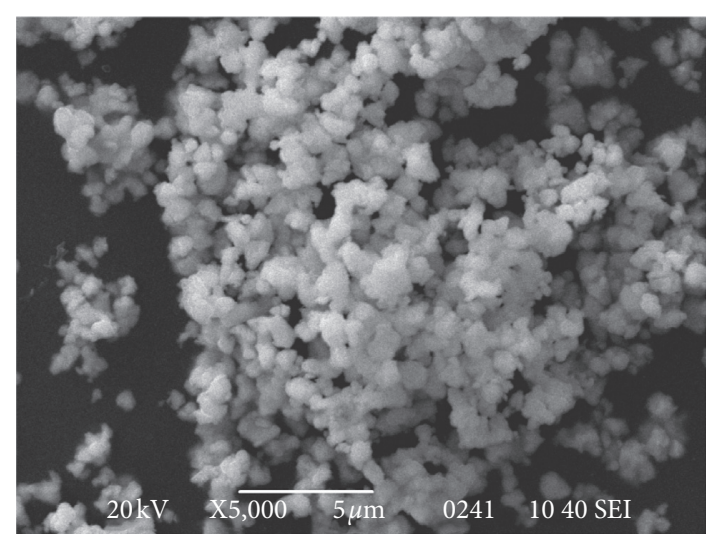

Figure 3: Microphotograph of the $\mathrm{La}_{1.4} \mathrm{Cd}_{0.6} \mathrm{MoO}_{5.7}$ sample.

The value of the unit cell parameter of fluorite-like phase and $\mathrm{La}_{5} \mathrm{Mo}_{3} \mathrm{O}_{16+\delta}$ lanthanum molybdate $(11.2400(3) \AA[9])$ is close. The substitution of lanthanum with cadmium, like reduction [9], leads to a decrease in the cell parameter.

When the unit cell parameter of the cubic structure starts declining, the reflections of the cadmium oxide phase appear in the X-ray patterns of the samples. In the region where the reflections of the cadmium molybdate phase are observed $(x>0.8)$, the unit cell parameter remains unchanged.

Lanthanum molybdate with the tetragonal structure transforms into the cubic fluorite-like phase of $\mathrm{La}_{5} \mathrm{Mo}_{3} \mathrm{O}_{16+\delta}$ in which the content of molybdenum is higher (by $4.5 \%$ if 


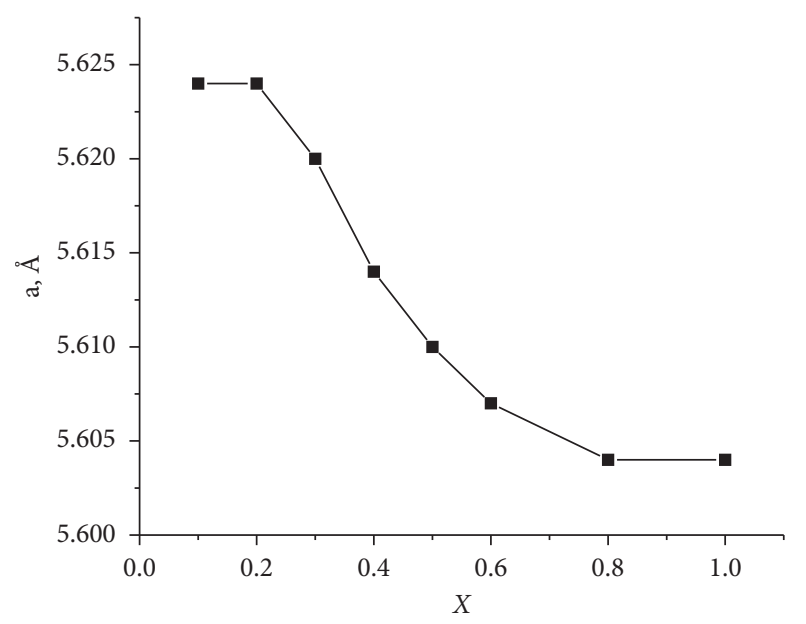

FIgURE 4: Dependence of cubic unit cell parameter $a$ of $\mathrm{La}_{2-}$ ${ }_{x} \mathrm{Cd}_{x} \mathrm{MoO}_{6-x / 2}$ on the content of cadmium $(x)$.

recalculating per molybdenum anhydride) than in $\mathrm{La}_{2} \mathrm{MoO}_{6}$. An assumption was made earlier that, in such compounds, the atoms of cadmium [16] or REE [18] can substitute (to a small extent) for the atoms of molybdenum in the $\mathrm{Ln}_{5} \mathrm{Mo}_{3} \mathrm{O}_{16+\delta}$ structure. According to this, a value of the unit cell parameter in this system depends on three factors simultaneously: first, the smaller ionic radius of cadmium than lanthanum (the values of ionic radii for coordination number 8 are $1.16 \AA\left(\mathrm{La}^{3+}\right)$ and $1.10 \AA\left(\mathrm{Cd}^{2+}\right)$ [19], respectively); second, the decrease in the amount of stoichiometric oxygen according to the electroneutrality principle; and the last, the cadmium atoms localization in the molybdenum sites of the crystal structure. The first two factors obviously result in the decrease of the unit cell parameter, but the reduction in oxygen content has a greater influence. Only the occupation of the molybdenum sites by the cadmium atoms can influence the expansion of the unit cell.

The first region of the plot of the unit cell parameter dependence on composition corresponds to formation and stabilization of the cubic phase which probably is due to the substitution of cadmium for lanthanum or the occupation of the molybdenum sites by cadmium occurring under the following schemes:

$$
\begin{aligned}
& \mathrm{La}^{3+}+1 / 2 \mathrm{O}^{2-} \longrightarrow \mathrm{Cd}_{\mathrm{La}}{ }^{2+}+1 / 2 \mathrm{~V}_{\mathrm{O}}(1) . \\
& \mathrm{Mo}^{6+}+2 \mathrm{O}^{2-} \longrightarrow \mathrm{Cd}_{\mathrm{Mo}}{ }^{2+}+2 \mathrm{~V}_{\mathrm{O}}(2) .
\end{aligned}
$$

A redistribution of molybdenum from the tetragonal structure to the cubic one also takes place. The edge of the top region possibly determines the limit of cadmium localization into the molybdenum sites.

The region where the unit cell parameter decreases linearly corresponds to the substitution of cadmium for lanthanum occurring in the formed cubic phase under Scheme 1 . The limit of this substitution is determined by the edge of the bottom region in the dependence and the appearance of the cadmium molybdate phase.

The $\mathrm{CdY}_{4} \mathrm{Mo}_{3} \mathrm{O}_{16}$ structure was used as the initial model [17]. The crystal structure refinement shows (see Figure 5)

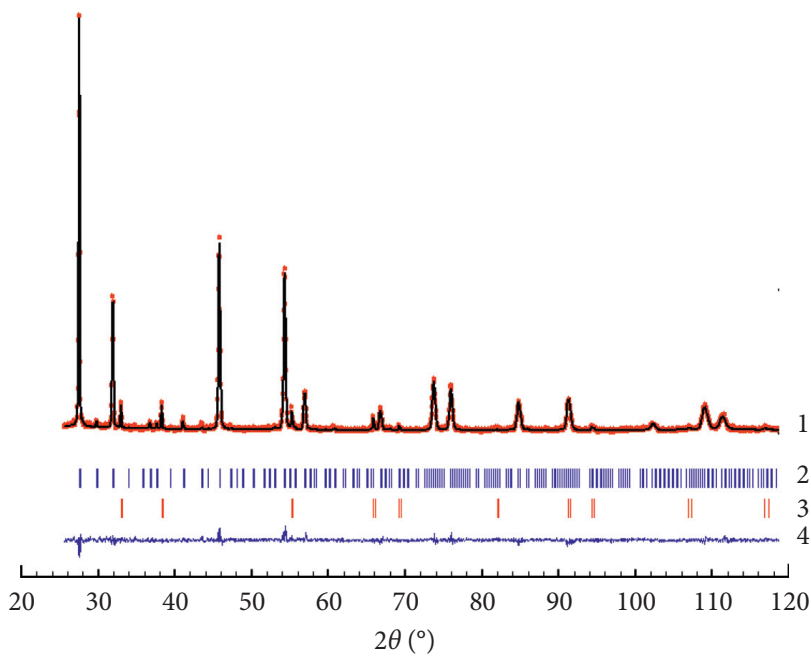

Figure 5: X-ray powder profiles for $\mathrm{La}_{1.4} \mathrm{Cd}_{0.6} \mathrm{MoO}_{5.7}$. (1)Circles: experimental data, line: calculated data; (2)position of the cubic phase reflections; (3)position of the CdO phase reflections; (4) differential profile.

that the cubic phase is crystallized in the space group Pn-3n with a double unit cell of fluorite.

Atomic coordinates and isotropic thermal parameters are represented in Table 2. Different atomic ratios in the molybdenum and REE sites of the crystal structure were compensated by the localization of a part of the cadmium atoms in the molybdenum sites. Then, a cadmium atoms redistribution refinement among the lanthanide sites showed that cadmium fully occupies the $8 \mathrm{c}$ position. After that, the occupation of the molybdenum site was refined.

With an increase in cadmium content, the unit cell parameter of the cubic structure decreases, but metal-oxygen interatomic distances decrease only for the $8 \mathrm{c}$ position reaffirming cadmium localization in this site (see Table 3 ).

The longer Mo-O interatomic distances in the cubic structure in comparison with the tetragonal one (1.779(1) [6]) signify a partial localization of cadmium in the molybdenum site and a distortion of the tetragonal environment.

IR spectra of lanthanum molybdate with the tetragonal and stabilized cubic structures are represented in Figure 6. According to work [20], the IR-spectrum of lanthanum molybdate with the tetragonal structure displays absorptions bands which can be assigned to internal vibrations of isolated $\mathrm{MoO}_{4}$ group: asymmetric stretching $\nu_{3}$ mode at 872 and $779 \mathrm{~cm}^{-1}$ and asymmetric bending $v_{4}$ mode at $501 \mathrm{~cm}^{-1}$. In the spectrum of $\mathrm{La}_{1.4} \mathrm{Cd}_{0.6} \mathrm{MoO}_{5.8}$ with the cubic structure, the bands observed at 893 and $853 \mathrm{~cm}^{-1}, 816$ and $772 \mathrm{~cm}^{-1}$, and $464 \mathrm{~cm}^{-1}$ correspond to symmetric stretching $v_{1}$ mode, asymmetric stretching $v_{3}$ mode, and asymmetric bending $\nu_{4}$ mode, respectively [20].

IR spectra of cubic lanthanum molybdate modified by cadmium are similar to spectra of neodymium molybdate $\mathrm{Nd}_{5} \mathrm{Mo}_{3} \mathrm{O}_{16+\delta}$ and its solid solutions [21] as well as a phase of cubic double cadmium and gadolinium molybdate [16] (see Table 4). 
TABLE 2: Rietveld structure refinement of the $\mathrm{La}_{2-x} \mathrm{Cd}_{x} \mathrm{MoO}_{6-x / 2}$.

\begin{tabular}{|c|c|c|}
\hline Content Cd $(x)$ & 0.5 & 0.6 \\
\hline $\begin{array}{l}\text { Impurity phase } \\
\text { Lattice parameters } a,(\AA)\end{array}$ & $\begin{array}{c}\mathrm{La}_{2} \mathrm{MoO}_{6}, \mathrm{CdO} \\
11.2170(4) \\
\end{array}$ & $\begin{array}{c}\mathrm{CdO} \\
11.2004(6) \\
\end{array}$ \\
\hline $\begin{array}{l}\text { Atom coordinates, }(x, y, z) \\
\text { La1, 12(e) } \\
(\mathrm{La} / \mathrm{Cd}) 2,8(\mathrm{c}) \\
\mathrm{Mo} / \mathrm{Cd}, 12(\mathrm{~d}) \\
\text { O1, 16(f) } \\
\text { O2, 48(h) } \\
\end{array}$ & $\begin{array}{c}0.0097(7) ; 1 / 4 ; 1 / 4 \\
0 ; 0 ; 0 \\
0 ; 3 / 4 ; 1 / 4 \\
0.110(3) ; 0.110(3) ; 0.110(3) \\
0.577(3) ; 0.371(2) ; 0.844(3)\end{array}$ & $\begin{array}{c}0.0083(8) ; 1 / 4 ; 1 / 4 \\
0 ; 0 ; 0 \\
0 ; 3 / 4 ; 1 / 4 \\
0.108(3) ; 0.108(3) ; 0.108(3) \\
0.574(2) ; 0.375(2) ; 0.850(3)\end{array}$ \\
\hline $\begin{array}{l}\text { Position occupancy } \\
\text { (La/Cd) } 2 \\
\text { Mo/Cd }\end{array}$ & $\begin{array}{c}\text { La } 4 ; \text { Cd } 4 \\
\text { Mo 10.8(4); Cd } 1.33\end{array}$ & $\begin{array}{c}\text { La } 2.93 ; \text { Cd } 5.07 \\
\text { Mo } 10.7(2) ; \text { Cd } 1.33\end{array}$ \\
\hline $\begin{array}{l}\text { Reliability factors } \\
\mathrm{R}_{\mathrm{p}} \\
\mathrm{R}_{\mathrm{wp}} \\
\mathrm{R}_{\exp } \\
\chi^{2} \\
\mathrm{R}_{\mathrm{B}} \\
\mathrm{R}_{\mathrm{f}} \\
\end{array}$ & $\begin{array}{l}8.76 \\
11.7 \\
9.33 \\
1.57 \\
3.49 \\
4.44 \\
\end{array}$ & $\begin{array}{c}10.3 \\
14.3 \\
12.65 \\
1.28 \\
5.51 \\
6.36 \\
\end{array}$ \\
\hline
\end{tabular}

TABLE 3: Selected interatomic distances $\mathrm{La}_{2-\mathrm{x}} \mathrm{Cd}_{\mathrm{x}} \mathrm{MoO}_{6-\mathrm{x} / 2}[\AA]$.

\begin{tabular}{lccc}
\hline Interatomic distances & Mult. & $x=0.5$ & $x=0.6$ \\
\hline $\mathrm{La} 1-\mathrm{O}$ & $\times 4$ & $2.70(3)$ & $2.71(3)$ \\
& $\times 4$ & $2.49(3)$ & $2.51(3)$ \\
$(\mathrm{La} / \mathrm{Cd}) 2-\mathrm{O}$ & $\times 6$ & $2.43(3)$ & $2.34(3)$ \\
$\mathrm{Mo} / \mathrm{Cd}-\mathrm{O}$ & $\times 2$ & $2.14(3)$ & $2.09(3)$ \\
& $\times 4$ & $1.92(3)$ & $1.98(3)$ \\
\hline
\end{tabular}

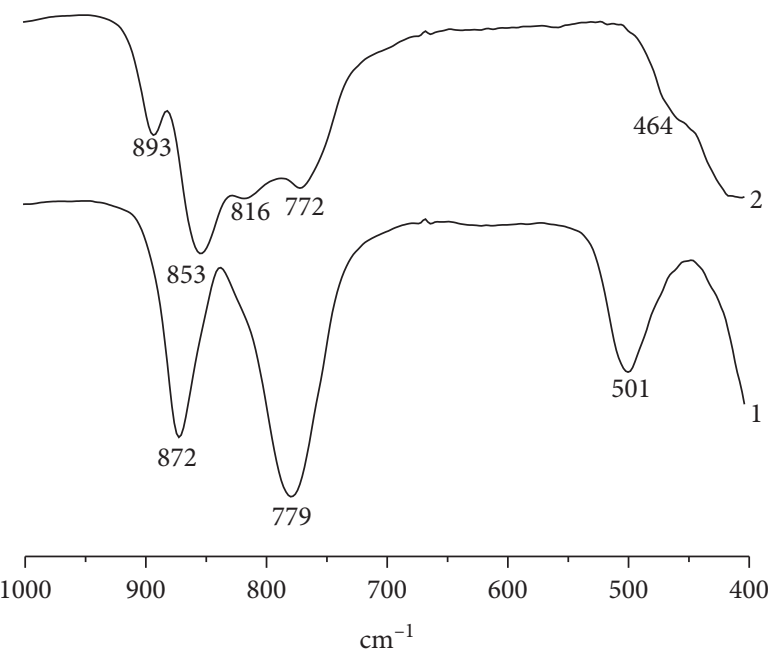

FIGURE 6: FTIR-spectra of the $\mathrm{La}_{2} \mathrm{MoO}_{6}(1)$ and $\mathrm{La}_{1.4} \mathrm{Cd}_{0.6} \mathrm{MoO}_{5.7}$ (2).

A larger number of active vibrations in the IR spectra of the $\mathrm{La}_{1.4} \mathrm{Cd}_{0.6} \mathrm{MoO}_{5.7}$ phase compared to $\mathrm{La}_{2} \mathrm{MoO}_{6}$ are possibly due to the fact that, in the structure of the cubic phase, $\mathrm{MoO}_{4}$-tetrahedra are connected in a special way through the ions of the rare-earth elements (see Figure 7).

Maximal content of the cubic phase, 94\%, was found in the sample $\mathrm{La}_{2-x} \mathrm{Cd}_{x} \mathrm{MoO}_{6-x / 2}$ with $x=0.6$. This sample also contains the cadmium oxide phase. The sample with $x=0.5$ consists of lanthanum molybdate with cubic and tetragonal structures and cadmium oxide phase. The simultaneous existence of lanthanum molybdate with tetragonal structure and cadmium oxide makes further interaction between these phases possible. An effort to obtain single-phase samples by increasing molybdenum content was made as molybdenum content in lanthanum molybdate with the tetragonal structure is lower than that in the cubic one. For this purpose, series of samples $\mathrm{La}_{1.5} \mathrm{Cd}_{0.5} \mathrm{Mo}_{(1+\mathrm{y})} \mathrm{O}_{5.75+3 \mathrm{y}}(y=0.1$, 0.2 ) were additionally investigated.

According to X-ray analysis, increase in molybdenum content in the samples results in a decrease of the reflections' intensities of the phases foreign to lanthanum molybdate (see Figure 8).

With the addition of the redundant quantity of molybdenum in the samples $\mathrm{La}_{1.5} \mathrm{Cd}_{0.5} \mathrm{Mo}_{(1+\mathrm{y})} \mathrm{O}_{5.75+3 \mathrm{y}}$, the unit cell parameter of the cubic phase decreases from 11.2170 (4) $\AA$ to 11.2011 (5) $\AA$. This change may be related to the occupation of the molybdenum sites by the bigger atoms of cadmium due to the lack of molybdenum atoms in the sample [16]. With increased molybdenum, content cadmium passes from the molybdenum sites to the lanthanum ones.

The heterovalent substitution of cadmium for lanthanide in tetragonal and monoclinic molybdates $\mathrm{Ln}_{2} \mathrm{MoO}_{6}$ leads to the cubic fluorite phase stabilization in a similar way as it occurs in the process of reduction by hydrogen. Thus, the oxygen content in the structure is crucial for the stabilization of the cubic fluorite-like phase.

The reduction of molybdenum by hydrogen in $\mathrm{Ln}_{2} \mathrm{MoO}_{6}$ molybdates leads to an increase of its ionic radius and creates prerequisites for a formation of coordination polyhedra for molybdenum ions with a larger coordination number than in the tetrahedron. It should be noted that, for reduced compositions, molybdenum in the lower oxidation states distributes statistically over the cationic positions of the fluorite structure while stabilized by heterovalent 
TABle 4: Assignment of the bands of the IR spectra.

\begin{tabular}{|c|c|c|c|c|c|}
\hline$v\left(\mathrm{~cm}^{-1}\right)$ & $\mathrm{La}_{2} \mathrm{MoO}_{6} *$ & $\mathrm{La}_{2} \mathrm{MoO}_{6}[16]$ & $\mathrm{La}_{1.4} \mathrm{Cd}_{0.6} \mathrm{MoO}_{5.7} *$ & $\mathrm{Gd}_{1.6} \mathrm{Cd}_{0.4} \mathrm{MoO}_{5.8}[10]$ & $\mathrm{Nd}_{5} \mathrm{Mo}_{3} \mathrm{O}_{16+\delta}[7]$ \\
\hline \multirow{2}{*}{$v_{1}$} & \multirow{2}{*}{872} & \multirow{2}{*}{865} & 893 & 890 & 907 \\
\hline & & & 853 & 855 & 848 \\
\hline \multirow{2}{*}{$v_{3}$} & \multirow{2}{*}{779} & \multirow{2}{*}{775} & 816 & 811 & 811 \\
\hline & & & 772 & 777 & 767 \\
\hline$v_{4}$ & 501 & 490 & 464 & 492 & 487 \\
\hline
\end{tabular}

*This work.

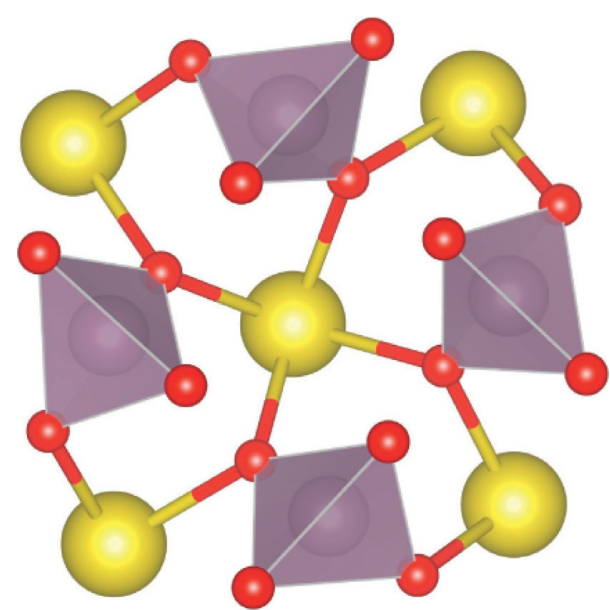

Figure 7: Crystal structure fragment of $\mathrm{Ln}_{5} \mathrm{Mo}_{3} \mathrm{O}_{16+\delta}$.

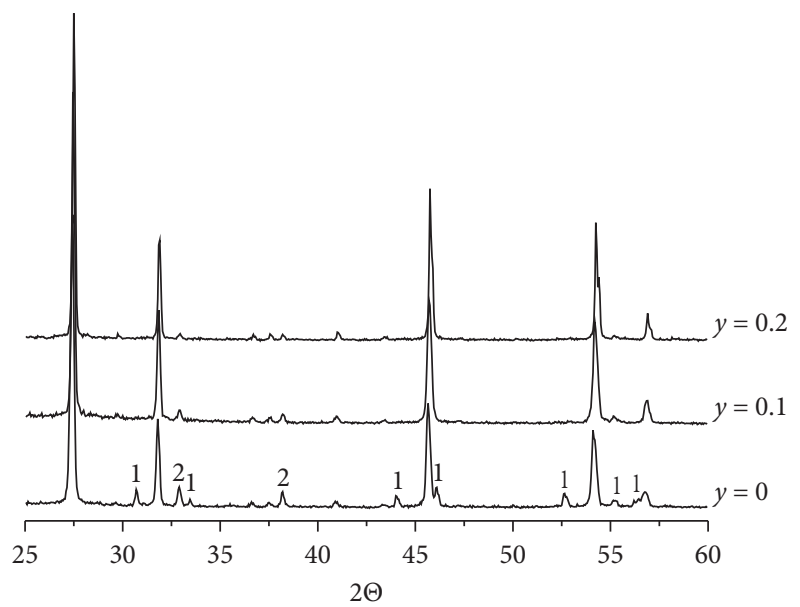

Figure 8: X-ray diffraction patterns of $\mathrm{La}_{1.5} \mathrm{Cd}_{0.5} \mathrm{Mo}_{(1+\mathrm{y})} \mathrm{O}_{5.75+3 \mathrm{y}}$. $1-\mathrm{La}_{2} \mathrm{MoO}_{6}$ (space group I41/acd); 2-CdO.

substitution compositions, molybdenum has a tetrahedral environment and locates orderly. This fact explains the absence of superstructure reflections on X-ray patterns for the reduced compositions and its formation in the case of cubic molybdates stabilized by heterovalent substitution.

\section{Conclusions}

(1) The cubic fluorite-like structure (space group, $\mathrm{P} n$ $3 n)$ in the system $\mathrm{La}_{2-x} \mathrm{Cd}_{x} \mathrm{MoO}_{6-x / 2}(0 \leq x \leq 1.0)$ was stabilized by the heterovalent substitution of cadmium for lanthanum
(2) The content of lanthanum molybdate with the tetragonal structure decreases as the degree of the substitution increases

(3) The maximum content, $94 \%$, of the cubic structure was found in the sample with $x=0.6$

(4) The Rietveld refinement of the crystal structure has revealed that cadmium ions preferably occupy the lanthanum (8c) sites and to a significantly lesser degree, the molybdenum (12e) sites causing a decrease in $\mathrm{La} / \mathrm{Cd}-\mathrm{O}$ distances and an increase in $\mathrm{Mo} /$ $\mathrm{Cd}-\mathrm{O}$ distances

(5) The possibility of stabilizing the cubic structure of lanthanum molybdate by substitution of lanthanum with cadmium is of great importance for regulating the functional properties of the compound

\section{Data Availability}

The XRD data used to support the findings of this study are included within the article.

\section{Conflicts of Interest}

The authors declare that they have no financial and personal relationships with other people or organizations that can inappropriately influence their work; there is no professional or other personal interest of any nature or kind in any product, service, and/or company that could be construed as influencing the position presented in, or the review of, the manuscript entitled "Investigation of the Heterovalent Substitution Cadmium for Lanthanum in Molybdate $\mathrm{La}_{2} \mathrm{MoO}_{6}$."

\section{References}

[1] F. Meng, X. Zhang, H. Li, and H. J. Seo, "Synthesis and spectral characteristics of $\mathrm{La}_{2} \mathrm{MoO}_{6}: \mathrm{Ln}^{3+}(\mathrm{Ln}=\mathrm{Eu}, \mathrm{Sm}, \mathrm{Dy}, \mathrm{Pr}$, Tb) polycrystals," Journal of Rare Earths, vol. 30, no. 9, pp. 866-870, 2012.

[2] F. De Smet, P. Ruiz, B. Delmon, and M. Devillers, "Evaluation of the role played by praseodymium molybdates in $\mathrm{Pr}_{6} \mathrm{O}_{11} \pm \mathrm{MoO}_{3}$ catalysts for the selective oxidation of isobutene to methacrolein," Applied Catalysis A: General, vol. 172, no. 2, pp. 333-349, 1998.

[3] E. I. Orlova, E. P. Kharitonova, N. I. Sorokina, T. A. Sorokin, A. M. Antipin, and V. I. Voronkova, "Structure and physical properties of Mg-containing oxymolybdates La2MoO6," Crystallography Reports, vol. 65, no. 5, pp. 697-703, 2020.

[4] A. A. Evdokimov, B. A. Efremov, B. K. Trunov, I. A. Kleinman, and B. F. Dzhurinskii, Rare Earth Substances, 
Molibdates, Tungstates, (in Russian), p. 267, Nauka, Moscow, RussiaNauka, 1991.

[5] J. A. Alonso, F. Rivillas, M. J. Martínez-Lope, and V. Pomjakushin, "Preparation and structural study from neutron diffraction data of $\mathrm{R}_{2} \mathrm{MoO}_{6}(\mathrm{R}=\mathrm{Dy}, \mathrm{Ho}, \mathrm{Er}, \mathrm{Tm}, \mathrm{Yb}$, Y)," Journal of Solid State Chemistry, vol. 177, no. 7, pp. 2470-2476, 2004.

[6] J. S. Xue, M. R. Antonio, and L. Soderholm, "Polymorphs of $\mathrm{Ln}_{2} \mathrm{MoO}_{6}$ : a neutron diffraction investigation of the crystal structures of $\mathrm{La}_{2} \mathrm{MoO}_{6}$ and $\mathrm{Tb}_{2} \mathrm{MoO}_{6}$," Chemistry of Materials, vol. 7, no. 2, pp. 333-340, 1995.

[7] A. M. Antipin, N. I. Sorokina, O. A. Alekseeva, A. P. Dudka, D. Y. Chernyshev, and V. I. Voronkova, "Polymorphism and structure of $\mathrm{Nd}_{2} \mathrm{MoO}_{6}$ single crystals," Crystallography Reports, vol. 62, no. 4, pp. 537-544, 2017.

[8] P.-H. Hubert, P. Michel, and A. Thozet, "Structure du molybdate de neodyme $\mathrm{Nd}_{5} \mathrm{Mo}_{3} \mathrm{O}_{16}$," Comptes rendus de l'Académie des Sciences, vol. 276, pp. 1779-1781, 1973.

[9] M. Tsai, M. Greenblatt, and W. H. McCarroll, "Oxide ion conductivity in $\left.\mathrm{Ln}_{5} \mathrm{Mo}_{3} \mathrm{O}_{16}+\mathrm{x}\right)(\mathrm{Ln}=\mathrm{La}, \mathrm{Pr}, \mathrm{Nd}, \mathrm{Sm}, \mathrm{Gd}$; $\mathrm{x}$. apprx. 0.5) with a fluorite-related structure," Chemistry of Materials, vol. 1, no. 2, pp. 253-259, 1989.

[10] P. H. Hubert, "Contribution a l'etude des molybdites des terres rares. II. -molybdites cubiques $\mathrm{Pn}_{3} \mathrm{n}$," Bulletin de la Société Chimique de France, vol. 3, no. 4, pp. 475-477, 1975.

[11] J. P. Faurie, "Preparation de nouvelles phases $\mathrm{MLn}_{4} \mathrm{Mo}_{3} \mathrm{O}_{16}$, $\mathrm{MLn}_{6} \mathrm{Mo}_{4} \mathrm{O}_{22}$ structure derivee du type fluorine," Bulletin de la Société Chimique de France, vol. 11, pp. 3865-3868, 1971.

[12] A. Mantidram and J. Gopalakrishnan, "Preparation and structure of some $\mathrm{Ln}_{2} \mathrm{MoO}_{5}$ oxides," Proceedings of the Indian Academy of Sciences-Section A, Chemical Sciences, vol. 87A, no. 8, pp. 267-273, 1978.

[13] A. Aguadero, M. J. Martínez-Lope, V. Pomjakushin, and J. A. Alonso, "Oxygen-deficient R2MoO6- $\delta(\mathrm{R}=\mathrm{Tb}, \mathrm{Dy}, \mathrm{Y}$, $\mathrm{Ho}, \mathrm{Er}, \mathrm{Tm}, \mathrm{Yb}$ ) with fluorite structure as potential anodes in solid oxide fuel cells," European Journal of Inorganic Chemistry, vol. 2011, no. 21, pp. 3226-3231, 2011.

[14] F. Shi, J. Meng, and Y. Ren, "Structure and physical properties of new phase oxide La2MoO5," Solid State Communications, vol. 95, no. 10, pp. 745-747, 1995.

[15] V. Voronkova, E. Kharitonova, E. Orlova, N. Gorshkov, and V. Goffman, "Synthesis and unusual properties of tetragonal $\mathrm{Pb}$-containing oxymolybdates based on $\mathrm{La}_{2} \mathrm{MoO}_{6}$ " European Journal of Inorganic Chemistry, vol. 2017, no. 47, pp. 55825587, 2017.

[16] E. I. Ge'tman, K. A. Chebyshev, L. I. Ardanova, and L. V. Pasechnik, "Synthesis, structure refinement and conductivity of Ln2-xCdxMoO6-x/2," Solid State Phenomena, vol. 230, pp. 45-50, 2015.

[17] J. B. Bourdet, R. Chevalier, J. P. Fournier, R. Kohlmuller, and J. Omaly, "A structural study of cadmium yttrium molybdate $\mathrm{CdY}_{4} \mathrm{Mo}_{3} \mathrm{O}_{16}$," Acta Crystallographica Section B Structural Crystallography and Crystal Chemistry, vol. 38, no. 9, pp. 2371-2374, 1982.

[18] A. M. Antipin, N. I. Sorokina, O. A. Alekseeva et al., "Structure of fluorite-like compound based on Nd5Mo3O16with lead partly substituting for neodymium," Acta Crystallographica Section B Structural Science, Crystal Engineering and Materials, vol. 71, no. 2, pp. 186-193, 2015.

[19] R. D. Shannon, "Revised effective ionic radii and systematic studies of interatomic distances in halides and chalcogenides," Acta Crystallographica Section A, vol. 32, no. 5, pp. 751-767, 1976.
[20] J. H. G. Bode, H. R. Kuijt, M. A. J. T. Lahey, and G. Blasse, "Vibrational spectra of compounds $\mathrm{Ln}_{2} \mathrm{MoO}_{6}$ and $\mathrm{Ln}_{2} \mathrm{WO}_{6}$," Journal of Solid State Chemistry, vol. 8, no. 2, pp. 114-119, 1973.

[21] K. A. Chebyshev, E. I. Get'man, L. V. Pasechnik, L. I. Ardanova, and D. V. Korotina, "Crystal structure and electrical conductivity of $\mathrm{Nd} 5-\mathrm{x} \mathrm{Sm} \times \mathrm{Mo}_{3} \mathrm{O}_{16}$ solid solutions," Inorganic Materials, vol. 51, no. 10, pp. 1033-1038, 2015. 